\title{
India and the Nuclear Suppliers Group (NSG) Membership
}

\section{Sario Bano*}

Abstract: The Nuclear Suppliers Group (NSG) was founded in 1974 in response to the Indian nuclear test to prevent the nuclear proliferation by controlling nuclear exports. In 2008, the NSG exempted India from its full scope safeguards (FSS) condition, making it first country to be allowed to have nuclear trade with NSG members along with its nuclear weapons program. India got this waiver after tough negotiations and resisted strong nonproliferation conditions. India is now bidding for the NSG membership. This paper analyses the prospects for the membership in light of the waiver negotiations and how the waiver negotiations can guide us about the likely path of membership. This study concludes that India will resist the non proliferation conditions and the U.S. and India have to invest massive diplomatic efforts to reach a formula that addresses the nonproliferation concerns of member states.

Keywords: Nuclear Suppliers Group, Indian waiver, the United States, NSG membership, Nuclear Nonproliferation Regime

* PhD candidate in Centre for Military and Strategic Studies (CMSS) at the University of Calgary 


\section{India and the Nuclear Suppliers Group (NSG) Members hip}

\section{Introduction}

The Nuclear Suppliers Group (NSG) is a multinational body that aims to prevent nuclear exports for peaceful purposes from being used to make nuclear weapons. The NSG was founded in 1974 in response to the Indian nuclear test that demonstrated that peaceful nuclear technology could be readily turned to nuclear weapons development. On September 6, 2008, the NSG exempted India from its guidelines, making it the first country that had not signed the NPT (Treaty on Nuclear NonProliferation) to be allowed to have nuclear trade with NSG members. India is now bidding for the NSG membership. On the one hand, it is argued that Indiaôs membership would strengthen the Group by bringing India closer to the regime. On the other hand, it is argue that exempting India once again from the NPT condition would undermine the Group. This paper analyses the prospects for India $\hat{o}$ NSG membership by focusing on the process of negotiations during the NSG waiver.

India received this waiver after tough negotiations. India got its exemption on the basis of certain non-proliferation commitments to which it agreed under the India-US Civilian Nuclear Agreement. These commitments included separating its civilian and military nuclear facilities in a phased manner; placing civil nuclear facilities under IAEA safeguards; signing and adhering to the IAEA's Additional Protocol; continuing its unilateral moratorium on nuclear testing; working with the United States for the conclusion of the Fissile Material Cut-off Treaty (FMCT); refraining from the transfer of enrichment and reprocessing technology to states that do not have them and supporting international efforts to limit their spread; introducing comprehensive export control legislation to secure nuclear material; $\square$ and adherence to Missile Technology Control Regime (MTCR) and Nuclear $\square$ Suppliers Group (NSG) guidelines. These non-proliferation commitments, according to proponents of the waiver, officially bring India into the non-proliferation fold and bringing a responsible state with nuclear weapons into the nuclear non-proliferation regime would benefit the regime.

The NSG is a voluntary organization whose guidelines are not legally binding, but the members are politically committed to abide by the Group guidelines and decisions. Opponents argue that this exemption could be a slippery slope for other nuclear suppliers and recipients. Some member states, like Austria, New Zealand, Ireland, Norway, the Netherlands, and Sweden wanted to include strong non-proliferation conditions in the waiver, but failed to get these conditions, as they were unacceptable to India. The United States had to revise the waiver draft three times to meet their concerns.

India is now lobbying to get NSG membership, which requires NPT membership as one eligibility criterion. It means that India would get an exemption from this NSG entry criterion. The waiver negotiation history shows that once again India has to face the stiff resistance and the demand for greater nonproliferation conditions but one can also assume that India would work hard to avoid any such conditions due to opposition at the domestic level. Like the waiver, India and the United States have to invest significant diplomatic energy to get the consensus. India is already abiding by the NSG Guidelines without being a member, and the gain of Indian adherence to the guidelines can be kept without adding India to the NSG and compromising the eligibility criterion. But if the NSG compromises on its eligibility criteria, it would tie India more closely.

This paper is divided into four sections. The first section describes the origin and evolution of the NSG. How the Group is different from the Zangger committee and how it is playing an important role in the nuclear nonproliferation regime by focusing on the nuclear supply side. The second section analyses the nonproliferation demands that India faced during the waiver negotiations and is likely to face during the membership negotiations. The third section focuses on the likely path of India $\hat{o}$ membership. What does waiver negotiations tell us in this regard and what factors can play an important role? The fourth section offers a conclusion. 


\section{Sario Bano}

\section{The Origins of the NSG}

From the beginning, nuclear suppliers felt the need for nuclear export controls to make sure that nuclear exports would not contribute to the nuclear proliferation. Nuclear export control provisions were part of the NPT negotiations and a nuclear export control committee $і ̈$ which became to known as the Zangger Committee after its first chairman Claude Zanggerï was set up to have a common understanding of the NPT provisions regarding nuclear exports and the items subject to safeguards. In 1975, in response to India $\hat{Q}$ nuclear test, the NSG was formed to broaden its scope beyond these NPT-related export control provisions.

\section{The Zangger Committee}

Different interpretations of the NPT article III (2)led to a need to form the Zangger Committee for precision. Article III (2) states that ñEach State Party to the Treaty undertakes not to provide: (a) source or special fissionable material, or (b) equipment or material especially designed or prepared for the processing, use or production of special fissionable material, to any non-nuclear-weapon state for peaceful purposes, unless the source or special fissionable material shall be subject to the safeguards required by this Article. $\grave{o}^{1}$

Neither the ñsource of special fissionable materialò nor ñequipment or material designed nor prepared for the processing, use or productionò of the material was defined in the treaty. Due to this lack of precision, in 1971, fifteen NPT states ${ }^{2}$ established the Zangger Committee to reach a common understanding regarding this article. In 1974, the committee defined the source or fissionable material and produced the Trigger List of material, equipment, and rules that should govern the exports of these items. ${ }^{3}$

Since its inception, the Committee has updated the Trigger List in light of developments in nuclear technology. The similarity in the tasks of the Zangger Committee and the NSG led to the question of maintaining two separate groups. Some suggested discontinuing one or amalgamating the both into one group. Others suggested maintaining the existing order in which the Zangger Committee stays strictly within the legal framework of the NPT, while the NSG has broadened its mandate beyond the limits of Article III (2) to include physical protection and dual-use technology control. $^{4}$

\section{The formation of the NSG}

The NSG was founded in 1974 in response to the Indian nuclear test that demonstrated that peaceful nuclear technology could be readily turned to nuclear weapons development. It was evident that the Nuclear Non-Proliferation Treaty (NPT) alone cannot prevent nuclear proliferation. This prompted nuclear suppliers to focus on the management of nuclear exports beyond the scope of the NPT and the Zangger Committee. Another objective was to bring France, then not an NPT member, into the nuclear exports fold. At first this supplier group was known as the ñThe London Clubò due to its regular meetings from 1975 to 1977 in London, and later it was officially named as the ñNuclear Suppliers Groupò. The original members ${ }^{5}$ agreed on the first draft of the Guidelines in 1977, which were published as the IAEAôs document INFCIRC/254 in February 1978. These Guidelines incorporated the Zangger Committee Trigger List in addition to heavy water items, reprocessing, and enrichment technology.

The NSG went beyond the context of the NPT to impose stringent conditions for nuclear exports. Some NPT developing states viewed the Guidelines as an excessive control on nuclear technology and violation of the NPT Article IV that grants them ñinalienable rightò to develop and use nuclear technology for peaceful purposes. These states, particularly India and Iran, criticized the 
NSG as tool of supplier states to retain their dominance in nuclear technology. To counter these repeated contentions, the United States sponsored three seminars, in 1997, 1999, and 2009, to explain the activities of the Group. ${ }^{7}$ These seminars were also in response to the 1995 NPT Review and Extension Conference that called for transparency in the nuclear export controls. In 2001 it was decided to create an official NSG website to bring further transparency. ${ }^{8}$

The NSG did not meet again until 1991. The revelations about the Iraqi nuclear weapons program led to the tightening of the nuclear exports controls. In March 1991, the Group met in The Hague to (a) update the Trigger List; (b) adopt full-scope safeguards; and (c) control dual-use technology. The 1977 Guidelines were updated and published by the IAEA as INFCIRC/254/Rev.1/Part1. The Group adopted the policy of requiring IAEA full-scope safeguards, covering all nuclear facilities and activities, as a condition of nuclear supply. Guidelines for the transfer of dual-use nuclear technology were also adopted and published as INFCIRC/254/Rev.1/Part2. ${ }^{9}$

The policy of full-scope safeguards placed nonproliferation ahead of nuclear trade. The 1995 NPT Review and Extension Conference endorsed this policy. ${ }^{10}$ The final document of the 2000 and 2010 NPT Review Conference also reaffirmed this principle, which shows the international communityôs support for this policy. ${ }^{11}$ In this way the non-NPT states ï India, Pakistan, and Israel (North Korea signed and then withdrew in 2003) ï that do not accept full-scope safeguards were no longer eligible to have nuclear trade with the NSG member states. On September 6, 2008, as part of the India-US Civil Nuclear Agreement, the NSG exempted India from its full-scope guidelines, making it the first country that had not signed the NPT to be allowed to have nuclear trade with NSG members.

\section{The NSG India -specific Waiver}

On July 18, 2005, U.S. President George W. Bush and Indian Prime Minister Manmohan Singh in a joint statement announced a framework for nuclear cooperation between the two countries, which brought an end to more than three decades of sanctions against India following its 1974 nuclear test. The United States had to change its domestic law to facilitate this nuclear cooperation. The Hyde Act, approved by the U.S. Congress and signed by President Bush into law on December 18, 2006, provides this waiver authority to the President, but contains seven conditions that must be met before exercising it. Among these requirements are a credible civil-military separation plan by India, an India-IAEA Safeguards Agreement and a consensus decision by the Nuclear Suppliers Group to exempt India from its export guidelines - specifically the full-scope safeguards requirement.

On September 6, 2008, the NSG agreed on an India-specific exemption to its nuclear export guidelines after complex negotiations. The exception, initiated by the Bush Administration and strongly backed by France, Russia, and the UK, was a remarkable development in the nonproliferation regime, reversing the NSG policy requiring full-scope safeguards as a condition of export, which was adopted in 1992. India is now the only non-NPT member allowed to engage in nuclear trade with the rest of the world, enjoying the benefits of nuclear trade reserved for NPT states without being required to sign the treaty. Many like-minded countries like New Zealand, Austria, Switzerland, the Netherlands, and Norway criticized the exemption for lacking any conditions and proposed amendments to its various drafts in view of their nonproliferation concerns. Their proposed amendments included clauses concerning a unilateral ban on fissile material, termination of the waiver if India detonated a nuclear weapon, and a "review" mechanism to assess India's compliance with nonproliferation commitments. India's insistence on a "clean and unconditional" waiver due to tough opposition at the domestic level made negotiations complicated, and the United States had to redraft the proposal draft three times in order to meet the some of the objections and reservations. 


\section{Sario Bano}

\section{(a) First Draft (March 2006)}

The initial proposed draft was circulated by the United States in early March 2006 for potential discussion during a Consultative Group meeting on March 22-23 in Vienna. ${ }^{12}$ This body meets in between the group's annual Plenary meetings and takes up issues related to the guidelines. In a general discussion of the U.S.-India nuclear cooperation, France, Russia, and the United Kingdom spoke in support of the proposal while several countries raised questions in view of their nonproliferation concerns. ${ }^{13}$

The nonproliferation community criticized the draftô particularly vague and weak language in paragraph four, in which individual members would decide whether India was meeting its nonproliferation commitments instead of having a broad-based appraisal. ${ }^{14}$ India, on the other hand, was not happy with the prescriptive clause in paragraph five which reiterated language from paragraph 4 (d) of the NSG Guidelines. That language stated that the NSG members would continue to strive for the earliest possible implementations of the full-scope safeguardsô This was tantamount to implying that the NSG expected India to accede to the NPT as a NNWS (Non Nuclear Weapons State), something that the Indian government had always resisted.

India made it clear that, according to its reading of commitments in the 2005 agreement, the United States was responsible for delivering a álean and unconditional exemptionôfrom the export guidelines of the Nuclear Suppliers Group. The Hindu quoted an Indian official as saying, áf anything, the fierce debate and the trust vote that the Manmohan Singh government has just won demonstrate that the Prime Minister has absolutely no wiggle room, if the NSG imposes conditions, India will reserve the right to walk away. $\hat{0}^{5}$ Draft language was moving back and forth at multiple levels between the two countries and eventually both countries agreed on a second draft that was álean and unconditionalôin that it did not contain any conditions other than those described in the 2005 agreement. The U.S. presented this draft at the August 21-22, 2008 NSG Plenary meeting for discussion approval.

\section{(b) Second Draft (13 August 2008)}

The second draft did not contain any additional restrictions on India and it certainly can be described as "clean and unconditional". There were no extraneous demands that India need to meet in order to get an exemption from the NGS guidelines. ${ }^{16}$ The NSG waiver is still conditional on India abiding by its commitments, but not in a way that calls for immediate termination. However, the termination of the waiver is linked with consultation in case India violates its nonproliferation commitments $ठ$ which requires a consensus decision.

In the 21-22 August NSG meeting, the draft moved by the U.S. was rejected by most members due to a lack of conditions. Media reports quoted unnamed diplomats. One diplomat said about the proposed draft that áhere are no conditions. Obviously what is missing is that (the waiver) is void if there is another atomic testô Another said

I think a majority of countries feel that the current draft is very weak and there is no conditionality at all ï I donâ really think that the U.S. expect that they are able to pass this draft. ${ }^{17}$

It was also reported that NSG members were divided into three groups according to their national policies towards the waiver. The first group of countries, which strongly supported the exemption, 
consisted of France, Russia, and the United Kingdom. The second group was ñike-mindedò countries like Austria, New Zealand, the Netherlands, Norway, Ireland, Sweden, and Switzerland, which wanted to include some conditions in the draft. The third group of countries, which came out in favor of the exemption but were not enthusiastic, included Germany, Japan, Canada, and Australia. ${ }^{18}$

The first group of countries, motivated by mercantile interests, strongly supported the waiver. The end of the ban on nuclear trade would open the Indian market for big vendors like Russia, France, and the U.K., which wanted their share in the nuclear trade along with the United States. The third group supported the waiver in large part to prevent India from refusing to favour their firms in getting Indian nuclear contracts.

The second group of countries, small states with a strong anti-nuclear stance, opposed the waiver as it stood and proposed conditions that would, they believed, make it a net gain for the nonproliferation regime. Austria led the opposition, refusing to accept the proposal on nonproliferation grounds and made it clear that it could not alienate the Green Party by changing its nonproliferation policy near its parliamentary elections. On August 21, 2008 Ulrike Lunachek, a prominent Green Party Leader, protested outside the NSG meeting and criticized the government for not taking a tough stance against the exemption. ${ }^{19}$ Interestingly, the austriantimes quoted an unnamed nuclear expert on 11 August 2008 as saying, óAustria will continue to grumble till the eleventh hour but is not likely to dissent on the day, Austria will never block the NSG alone, Austria is close to the U.S. these days. $\hat{0}^{0}$

Three countries, New Zealand, Austria, and Switzerland raised questions, during a special briefing by India on the sidelines of the NSG meeting, as to why the exemption should be made when India had not signed the NPT and the CTBT. ${ }^{21}$ Ireland, which played an initiating role in the development of the NPT and was the first country to sign the treaty, had a strong and deep commitment to the treaty, and was the obvious critic of the waiver. The Irish spokeswoman, in a press conference, said

Consistently over the past three years since the Indo-U.S. deal was first mooted Ireland has been to the fore in raising questions and expressing serious concerns particularly about its effects on the international nonproliferation regime. ${ }^{22}$

A Swiss foreign ministry spokesman also said óAn exemption for India would have severe consequences for the nonproliferation systemô ${ }^{23}$

NSG member states, especially the dike-minded states, ô proposed amendments on each paragraph of the draft. These suggestions mostly revolved around fears that India was getting the waiver on óoluntaryônonproliferation commitments, and the NSG would not be able to do anything if it reneged on its commitments. About the proposed amendments, a European diplomat said đo think the whole thing will be reformulated, but in a positive wayô ${ }^{24}$ The proposed amendments included the following ideas:

First, eventual accession to full-scope safeguards was one of the ideas that were debated in the NSG meeting. Reports quoted an unnamed diplomat as saying

There was a reference in the earlier U.S. draft to the desirability of India eventually accepting the NPT and its safeguards that was more positive than what we have now. So, I think America will have to come back to us with a new draft before any decision is possible. ${ }^{25}$ 


\section{Sario Bano}

Some member states insisted on a clause that would restate the desire of the Group for universal membership in the NPT. The reports quoted diplomats who could not understand the Indian objection to such a clause, which would only repeat the belief of the group in encouraging all countries to accede to the NPT. One diplomat said, d́ndia is not a member of the NSG so any such statement of principle by us would clearly not be binding on them,ô but at the same time the diplomat acknowledged that the group was áware of the sensitivity the issue had already raised in India following an earlier American attempt to incorporate this notion in the draft waiverô One of the NSG officials also added, đ́ think this is one issue the NSG is likely to back away from if the U.S. comes back in September and says India will simply not agree to thisố ${ }^{26}$

Second, on Indiaô nuclear testing moratorium, most of the member states emphasized a legally-binding testing moratorium. Although India committed itself to continue its unilateral moratorium on nuclear testing, it was suggested to provide some legally-binding assurances such as signing the CTBT (Comprehensive Test Ban Treaty). A diplomat is quoted as saying, óvhen every single member country of the NSG has signed the CTBT, why should India get a free passô ${ }^{27}$ Another diplomat also said óNobody seriously expected India to sign the CTBT as a precondition for the waiver. What needs to be looked at is how to deal with the new situation which would be created were India to test againô ${ }^{28}$ Some countries suggested conditioning the waiver on India $\hat{Q}$ signing the CTBT and others recommended that there should be some mechanism to deal with the situation if India tested a nuclear weapon and was not willing to sign the treaty. Some members called for automatic termination of the waiver in case of an Indian test, while others wanted to leave this to the individual member countries. It is important to note here that only U.S. domestic laws provide for immediate termination of the nuclear trade in case of a nuclear test.

Third, due to uncertainty about Indiâ̂ compliance with the nonproliferation commitments, it was also suggested to incorporate a óeviewôprovision in the proposed waiver draft. A report quoted one diplomat as saying, ósome countries are suggesting having some kind of monitoring mechanism to assess the extent to which India is abiding by its nonproliferation commitmentsô He also added that some countries suggested that individual members make their own national assessments, rather than having the group to assess Indiaôs compliance. ${ }^{29}$

Fourth, the question of enrichment and reprocessing (ENR) technology was also a contentious one. Some member states wanted to include a provision denying the transfer of ENR technology. Now that the NSG has agreed on new guidelines which require NPT membership, India vehmently criticized the decision that this is against the álean waiverô The NSG has made it clear that the waiver exempted India from the requirement of FSS safeguards but not NSG policies on ENR transfer. $^{30}$

In this meeting, the ơike-mindedôcountries also issued a joint statement. It said that they were ótrong supporters and defenders of the Nuclear Non-Proliferation Treaty (NPT), one of the most universal Treaties in the world today, and the most successful arms-control instrument the world has knownôand that their amendments were óbased on concepts already enshrined in UN Security Council Resolutions, in domestic legislation of NSG Participating Governments and in bilateral nuclear supply agreements which NSG Participating Governments have concluded over the yearsô ${ }^{31}$

In this statement, one UN Security Council Resolution alluded to is UNSCR 1172, which calls on India and Pakistan to give up their nuclear weapons programs. ${ }^{32}$ The reference to the domestic legislation of the NSG Participating Governments pointed to the Hyde Act which compells the U.S. government to terminate the nuclear trade immediately in the case of a nuclear test, a matter that was left unaddressed in the U.S.-India bilateral agreement. 


\section{India and the Nuclear Suppliers Group (NSG) Members hip}

\section{(c) Third Draft (3 September 2008)}

The United States and India agreed on an amended draft on August 29, 2008, after hectic negotiations. ${ }^{33}$ When the draft was presented in the NSG Plenary meeting on September 4, media reports indicated that the dike-mindedôcountries were not satisfied with the changes: great diplomatic effort was still to get the outcome desired for the U.S. and India. One diplomat said

It is clear that the package which is before us (NSG) still needs some work to achieve the outcome which can be the net gain to the quality of international security architecture. A number of measures have to be added to the current package before it can be considered to be a net gain for the world.

Another diplomat added, ó he NPT is one of the pillars of this architecture and nothing should undermine this. Reaching an agreement which will benefit everybody concerned will require imagination and creativityô $\hat{0}^{34}$

At this point, the dike-mindedôstates did not insist on the inclusion of a prescriptive clause regarding the eventual accession of India to the NPT, but they still wanted to include the explicit clauses on nuclear tests and a óeviewômechanism. Reports quoted one diplomat as saying, ólhis is very disappointing text from the point of view of the three major issues raised last time on testing, transfer of sensitive technologies and reviewô He described the consultation formula on testing as óagueôand said that no attempt had been made to address the ósensitive technologyôissue at all. đ́ donâ see how they expect us to accept itô ${ }^{35}$

On nuclear testing, Ireland, Austria, and New Zealand insisted on including automatic termination of the waiver in the event of India $\hat{s}$ violation on any of its nonproliferation commitments. They proposed to incorporate the Hyde Act provisions in the waiver, but France and Russia resisted due to their fears that it would jeopardize their investment in the Indian market. Automatic termination of the waiver remained a stumbling block, but one diplomat was quoted as saying it cónas been our absolute bottom line from the beginning and there is no question of it being droppedô At the same time, he conceded that, more than India, it was the óbig supplier nationsôlike Russia and France that were opposing automaticity of termination. óWe know the U.S. is committed to terminating supplies [if India tests] but we donâ want to leave the decision within the NSG to each individual PG [participating government] $\hat{\mathrm{O}}^{36}$ But another diplomat commented on the automatic termination of the waiver in these words: óMembers will not accept automaticity of termination of supplies at the NSG level either. We could and should hold consultations, but termination has to be a decision of individual governmentsô Another diplomat added, ólhe problem here is that the NSG works only on the basis of consensus. So if India did another test the follow-up meeting could be reduced to a talk shop by any member like America $\hat{0}^{37}$

Supporters of the waiver pressed for it in its presented form, but a diplomat commented, áhe main battle has to be waged by your (Indiâิ) principal partner, the U.S. ${ }^{38}$ After the meeting on 4 September, another diplomat from a western European country predicted about the Meeting on September 5, á see no reason why, if a push is made by the big players, consensus cannot be reached by tomorrow night. There are issues which need working but there seems to be a good possibility of sorting these out $\hat{0}^{39}$ ó he number of countries who favor this going through now is quite large, certainly more than before,ôanother diplomat added. ${ }^{40}$ There was also a growing realization that it was no longer possible to extract more nonproliferation commitments from India. A diplomat from a former Soviet Bloc state said óEveryone knows what India cannot accept so it is pointless to try and reach a consensus that India cannot supportôdt certainly seems like nobody really wants to be seen as blocking the consensus this time,ôanother added. ${ }^{41}$ 


\section{Sario Bano}

A compromise formula was also suggested, in which the concerns of the dike-mindedôstates would be reflected in a chairmanôs statement, but the dike-mindedôstates were not pleased with this formula. A diplomat told the media, ó here was a version of a chairmanôs statement that was circulating when it was pulled at the request of the Government of India. But from our point of view, this is not a runner. We want an unambiguous, clear waiver in one textô ${ }^{42}$

| 66 For the óike-mindedô states, nuclear testing remained the stumbling block. India and the United States after consultations with them introduced further changes in the draft. With this these negotiations, India and the U.S. and then óike-mindedôstates and the U.S., it was expected to extend the meeting to 6 September. A diplomat from the dike-mindedô states noted about the lengthy negotiations between the U.S. and the dike-mindedô states ó here are still very different views on both sides. We made some progress on minor issues but on the principal questions, there has been no movementô He added, đ́ canô see any way to bridge the divideô óvot unless a major shift in position [by India and the U.S.] occursô ${ }^{43}$

The first sign of improvement in this stalemate was the release of a formal statement (on the suggestion of Germany) by Indian External Affairs Minister Pranab Mukherjee reiterating Indiaôs nonproliferation commitments, including the unilateral moratorium on nuclear testing, not engaging in an arms race, no-first-use of nuclear weapons, and not being a source of proliferation of sensitive technologies. ${ }^{44}$ In the statement, a reference was also made to Indiaôs working paper on Nuclear Disarmament to the UN General Assembly calling for óglobal, non-discriminatory, and verifiable elimination of nuclear weapons within a specified timeframeô ${ }^{45}$ The Hindu quoted an Indian official about the usefulness of the reference to this working paper: óTomorrow if some NSG member questions our adherence to the commitments referred to in the waiver, we can just as easily turn around and ask why they are not supporting our move at the U.N. for the time bound elimination of nuclear weaponsô ${ }^{46}$

The release of a formal statement was a positive step, but the dike-mindedôstates remained unimpressed. One diplomat from the dike-mindedôstates told the media, óWe welcome it but it is not enough to resolve the outstanding difficulties with the main text [of the waiver]. Voluntary declarations do not have the same value as agreed NSG textô ${ }^{47}$

The ớike-mindedôstates continued to focus on the automatic termination, and India resisted this killer amendment, arguing that it had no option but to walk away if this clause was incorporated in the draft. This was the time óvhen the Norwegians, Dutch and others suggested making a reference to the Indian statement in the chapeau of paragraph $3 \hat{o}^{48}$ Eventually India agreed to the suggestion and the reference of the statement was incorporated in the revised draft.

\section{(d) Final Draft (6 September 2008)}

As the dike-mindedô states insisted on strong conditions linking the waiver and the Indian nonproliferation commitments, the U.S. and India had to introduce further changes in the draft. The final draft contained the minor changes but still lacked substantial changes. ${ }^{49}$

The changes from First to Final Draft indicate that the United States was trying to accommodate the nonproliferation concerns but still not cross Indian red-lines. The first paragraph shifted the focus to the energy needs of India, integrity of the nonproliferation regime, safeguards, and export controls as the objective of the waiver. In the second paragraph, India $\hat{Q}$ nonproliferation commitments were described and replaced the q́perpetuityô of safeguards with the reference to GOV/1621 and sharpened the language a bit more regarding India $\hat{Q}$ nonproliferation commitments. The third paragraph made a direct link between the waiver and Indiaôs commitments and also brought in the reference to Indiaôs formal statement on 5 September 2008. In case of Indiaôs violation, such as a nuclear test, the member states would meet to decide on the termination of the waiver but it would 


\section{India and the Nuclear Suppliers Group (NSG) Members hip}

require a consensus. The fourth paragraph requested the NSG chair to consult India regarding NSG Guidelines implementation by India.

The final draft can be seen as the desired álean and unconditionalôwaiver as it does not place any conditions on India. Indiaôs inflexibility regarding any conditions and its threat to withdraw from the agreement kept the negotiations on hard track. The dike-mindedôstates reluctantly approved the draft, and the NSG unanimously approved the India-specific exemption. This waiver lifted the rule of full-scope safeguards for India after 16 years. Proponents called it a net gain for the nonproliferation regime while opponents described it as a ónonproliferation disasterô ${ }^{50}$ Reports quoted one diplomat as saying, of For the first time in my experience of international diplomatic negotiations, a consensus decision was followed by complete silence in the room. No clapping, nothing. It showed a lot of us felt pressured to some extent into a decision by the Americans and few were totally satisfiedô ${ }^{51}$ óNPT RIP (Rest In Peace)Q̂ another diplomat added. ${ }^{52}$

A pro-waiver diplomat was quoted in these words: ôt was an incredibly complicated political and technological negotiation. In the end 45 countries came together to support Indian energy requirements and welcome it into the worldôs nonproliferation streamô ${ }^{53}$ Talking about the impact of the formal statement by Mr. Mukherjee, one European diplomat was quoted as saying, áf you ask me to identify a turning point in our work it was the circulation of that statementô ${ }^{54} \mathrm{John}$ Roods, head of the U.S. delegation in Vienna, also said that the statement created óositive momentumôto efforts to agree to an NSG waiver. ${ }^{55}$ This is surprising, as the dike-mindedôstates wanted to link the waiver to strong nonproliferation conditions and the Mukherjee statement offered nothing new, only a reiteration of the voluntary commitments that had already been stated in the draft.

Three factors played a pivotal role in this regard. First, media reports quoted several diplomats and U.S. officials who stated that the dike-mindedôstates eventually agreed to the waiver after two informal assurances. These were that no member state had a policy to transfer sensitive nuclear technology to India and that the member states would have nuclear trade with India after taking into account its compliance with its nonproliferation commitments. The Washington Post quoted a senior U.S. official as saying, đ́n the discussion about how to handle enrichment and reprocessing, it was made clear that nobody had any plans to transfer such technologies to India in the foreseeable futureô ${ }^{56}$ These two assurances were meant to address the concerns of the member states regarding the óban on sensitive technologyôand the ớeviewômechanism to assess Indiaôs compliance with its nonproliferation commitments in an informal way.

Second, The Hindu wrote about a conversation with a diplomat in these words, óthe diplomat added that his government and many others, had reiterated these assurances in their national statements before adoption of the waiver decision. Though there was no separate chairmanôs statement elaborating these assurances, the diplomat said the national statements now formed part of the NSGQ̂ internal records and could always be referred to in the futureô ${ }^{57}$ Austria, New Zealand, Ireland, Norway, Switzerland, Japan, Germany, and China made their national statements and expressed their concerns and expectations regarding the draft. A common perception was to terminate trade if India resumes nuclear testing. ${ }^{58}$

Third, intense American diplomacy along with France, Russia, and Britain also played an important role in reaching the consensus. The Bush Administration was keen to get approval as it had only weeks to get the Congressional approval of the U.S.-India agreement before the November election. Nucleonics Week quoted a diplomat from a uranium exporting country as saying, ôn the end, most of the true nuclear suppliers in NSG are going to support the exemption request with few changesô It was also added that France and Britain urged the đEU as a whole to support the US initiative on Indiaô ${ }^{59}$ Reports quoted many diplomats as saying, óntense U.S. pressure for the waiver involved oversight phone calls to Presidents and Prime Ministers of holdout countriesô $\hat{0}^{60}$ The U.S. 


\section{Sario Bano}

administration officials are quoted as saying, óRice made at-least two dozen calls to lean on allies to allow for the India-Specific waiverô ${ }^{61}$

\section{Indiaâ bid for the NSG membership}

| 68 India is likely to be an exporter of nuclear technology like fast breeder and thorium based reactors and it is in the interest of the NSG to have all possible nuclear exporter countries in the group. Dr. S. Banerjee, chairman of the Indian Atomic Energy Commission, in his remakes at the $54^{\text {th }}$ session of the General Conference of the IAEA mentioned that the Nuclear Power Corporation of India Limited (NPCIL) is ready to export $220 \mathrm{MWe}$ and 540MWe capacity PHWRs. ${ }^{62}$ U.S. President Obama announced his support for India's membership in the NSG during his official visit to India in November 2010. ${ }^{63}$ On November 8, 2010, in the India-US joint statement, the United Stated supported Indiaô full membership in the four multilateral export control regimes (Nuclear Suppliers Group, Missile Technology Control Regime, Australia Group, and Wessenaar Arrangement) in a phased manner. India, on its part, committed to harmonize its export controls with those of all the four multilateral export control regimes. ${ }^{64}$ India has updated its atomic transfer control list to the standards of export control regimes especially NSG and MTCR $^{65}$ and argues that in November Joint Statement there was no nonproliferation condition and for NSG membership India already fulfills the criteria. Nirupama Rao, Indian Ambassador to the United States, also expressed the same views about India $\hat{Q}$ eligibility and termed the membership as ña matter of timeò ${ }^{66}$ It is important to note that the NSG waiver already commits India to harmonize its export controls to the NSG guidelines.

France,${ }^{67}$ Germany ${ }^{68}$ Russia, ${ }^{69}$ Australia, ${ }^{70}$ and the United Kingdom ${ }^{71}$ have also announced support for India's NSG membership. For Indiaôs membership, the NSG again has to exempt India from its NPT condition. In 2011, the US drafted the ñfood for thoughtò paper for possible discussion and offered two options for bringing India into the group. First, revise the admission criteria ñthat would accurately describe Indiaôs situationò. Second, recognize that ñfactors to be consideredòare not ñmandatoryò and a state can be admitted without meeting all the factors by consensus decision. ${ }^{72}$ The United States is in the favor of this second option. ${ }^{73}$ Current ñfactors to be consideredò are

ñA new Participating Government should:

- $\quad$ be able to supply items1 covered by the Annexes to Parts 1 and 2 of the Guidelines;

- $\quad$ adhere to and act in accordance with the Guidelines;

- $\quad$ have in force a legally-based domestic export control system which gives effect to the commitment to act in accordance with the Guidelines;

- $\quad$ be a party to the NPT, the Treaties of Pelindaba, Rarotonga, Tlatelolco or Bangkok or an equivalent international nuclear non-proliferation agreement, and in full compliance with the obligations of such agreement(s), and, as appropriate, have in force a full-scope safeguards agreement with the IAEA;

- $\quad$ be supportive of international efforts towards non-proliferation of weapons of mass destruction and of their delivery vehicles. $0^{74}$

India meets all the above-mentioned factors except to r̃oe a party to the NPTò. The NSG annual meetings in 2012 and 2013 discussed Indiaôs membership issue but consensus could not develop due to the opposition from the like-minded countries. In a 2013 meeting, Britain circulated a paper and lobbied for India $\hat{s}$ membership and argued that India is eligible due to its large size civilian nuclear industry and its commitments to nonproliferation. Due to these reasons, ñthe NSG is best served by the inclusion and membership of Indiaò, the paper argued. ${ }^{75}$ China, however, opposed Indiaôs membership and called for áquitable policies toward all countries in the regionò referring to its ally 


\section{India and the Nuclear Suppliers Group (NSG) Members hip}

Pakistan which is also outside the NPT. Ireland, the Netherland, and Switzerland raised concerns over this issue. Japan was also not favorable to the idea ${ }^{76}$ One diplomat voiced uncertainty and said, ñthere are several countries in each camp. I am not sure how it can be moved forward..$^{77}$ Another diplomat argued that his country wants ña serious discussionò about its implications for the implementation of NSG guidelines. He was optimistic about finding a formula that is not ñdamaging to the NPTò, for example, signing the CTBT. That would be an ñextremely high-value symbolic stepò that does not have an immediate impact on India, as the treaty will not enter into force unless seven other countries ratify it. ${ }^{78}$ Another diplomat also commented in an optimistic way that ña number of countries have continued doubtsò but no one ruled out the possibility of India $\hat{\alpha}$ membership. ${ }^{79}$ Looking at the NSG waiver negotiations, we can better assess the hurdles that India has to face for its membership.

The negotiation of the waiver shows that, despite India's arguably strong nonproliferation record and stable democracy, it was not easy for the United States to get the exemption: it had to revise the draft three times to address the concerns of some NSG member states, and mount significant diplomatic efforts at the end. It is expected that Indiaôs admission would meet tough resistance and like-minded countries would again demand greater nonproliferation conditions. These conditions, like signing the CTBT, curtailing the production of fissile material, and restraining its nuclear weapons program through IAEA safeguards on additional nuclear facilities ${ }^{80}$ or freezing further development of long-range ballistic missiles that could carry nuclear weapons, ${ }^{81}$ are likely to be pressed.

Indiaô membership debate also highlights the NSG relationship with non-NPT states. Some countries are of the view that developing a criteria-based approach comprising tough nonproliferation conditions, will allow non-NPT states to be included in the NSG. Others argue that this would weaken the NPT, which is the primary bargain and the most important multilateral treaty in the nonproliferation regime. One diplomat stated, ñthere are differences of opinion on allowing non-NPT members into the NSG.ò The NSG waiver negotiations shows that the NSG made the waiver Indiaspecific, which reduces the possibility of the waiver leading to a criteria-based approach to further waivers, while the Hyde Act specifically limits the United States in this regard. The initial discussions on the membership also signals for India-specific pattern.

India is likely to face strong demand for legally binding nuclear test moratorium. Likeminded states in the membership discussion stressed the need for signing CTBT to demonstrate Indiaôs commitment with the nonproliferation regime. It is important to note that India fought hard to keep its nuclear testing option open both in India-US Nuclear Agreement and the NSG waiver negotiations and only committed to continue its moratorium on nuclear testing. India is also resisting this condition strongly in Japan-India Nuclear Agreement Negotiations. This shows that India would resist this condition in the membership negotiations too and like the Parnab Mukerjee statement in the waiver, India and the United States have to work around this demand.

It is also expected from the like-minded states to demand for unilateral moratorium on the production of fissile material. The India-US Nuclear Agreement and the NSG waiver failed to commit India to stop the production of fissile material for weapon use. The Indian strategic community opposed any condition including signing of CTBT, FMCT, and MTCR at the cost of NSG membership. ${ }^{82}$. India $\hat{Q}$ strategic community also argued that apart from ñsymbolic valueò India is not gaining anything or loosing anything from NSG membership. The NSG waiver gave a major boost to the Indian civilian industry and to accept conditions for the membership would compromise its deterrence ability, which India should not accept. ${ }^{83}$ It would constrain its nuclear weapon program and sovereign right to determine its security policy.

Given India $\hat{Q}$ domestic situation, it can be argued that India would resist additional conditions and India and the US again have to mount significant diplomatic efforts to assuage the concerns of the like-minded states. The Bush Administration wanted to conclude the India-US 


\section{Sario Bano}

agreement in its tenure, therefore, dealt the NSG waiver as an urgent matter and invested enormous diplomatic energy. The U.S. support for Indiaô NSG membership will be less vigorous than its support for the waiver. India has to share more of the diplomatic burden to present its case. India is again pressing its case vigorously, dispatching high-level diplomatic officials to the capitals of the NSG member states to convey its position and limitations. ${ }^{84}$ It is also holding side-meetings during the NSG meetings to address the nonproliferation concerns of the member states. ${ }^{85}$ It has to mobilize support expressed by key member states to convince the other member states, particularly likeminded states.

It can be argued that India would not accept additional nonproliferation conditions and both sides again have to come to a formula that works around these nonproliferation demands. Once the like-minded states are on board, it would be unlikely for China to block the consensus. ñThere are good reasons for having it (India) in the clubò however getting there would be a ñslow processò. A western diplomat said. ${ }^{86}$ India has not applied formally for the membership and is waiting for a broad international support.

\section{Conclusion}

India $\hat{Q}$ membership debate gave rise to divergent views. On the one hand, India is already adhering to the NSG guidelines as a nonmember state and admitting India would not strengthen international export controls. Admitting non-NPT states would not only complicate the decision-making process due to consensus rule, it would also undermine the credibility of the Group ${ }^{87}$ It would solidify the impression that India is now an accepted non-NPT state and it would eliminate incentive for India $\hat{\Theta}$ compliance with nonproliferation norms. ${ }^{88}$ On the other hand, it would tie India closer to the regime and enhance the credibility of the Group by having a leading NAM country in it. It would encourage India to adopt tight export control laws by increasing its stake the regime.

If we look at the NSG waiver negotiations for India, it is quite obvious that the waiver was India-Specific and now membership is likely to be limited to India. The final text of the waiver excluded references to the NPT and to Non-Nuclear Weapon States. Some NSG member states supported the waiver, while others opposed it and wanted to introduce more and stronger nonproliferation commitments. India, on the one hand, agreed to adhere to the NSG guidelines (both present and future) but, on the other hand, refused to commit to a legally binding nuclear testing moratorium, a ban on enrichment and reprocessing technology, automatic termination of the waiver in case it violates its non-proliferation commitments, and a review mechanism to monitor India's commitments. By adhering to the NSG guidelines, India has accepted the regime, which it has long criticized and discarded as "discriminatory". This is a positive development but it could have been made a real gain for the regime if the waiver had more non- proliferation commitments.

During the negotiation of the waiver, no NSG member state opposed it, but some wanted to include strong nonproliferation conditions. India's stable democracy, arguably strong nonproliferation record, and its growing economy needing energy, all played an important role in this regard. Like the waiver, India would resist the nonproliferation conditions in membership negotiations too. For the U.S. and India, it would not be easy to assuage the concerns of like-minded states. However, U.S. support will apparently be less vigorous and India has to invest more diplomatic efforts to square the circle. Like the waiver, India will get the membership but that seems to be a long process.

\section{Notes}

\footnotetext{
${ }^{1}$-Text of the NPT available at http://www.iaea.org/Publications/Documents/Infcircs/Others/infcirc140.pdf
} 


\section{India and the Nuclear Suppliers Group (NSG) Members hip}

2 - Australia, Austria, Canada, Denmark, Finland, Germany, Irelands, the Netherlands, Norway, Poland, Soviet Union, Sweden, Switzerland, United Kingdom, United States.

3 - These items in the Trigger List are in the Article XX and the IAEA Statute. Text of the IAEA Statute available at http://www.iaea.org/About/statute_text.html

4 - Fritz W. Schmidt, ñNPT export Controls and the Zangger Committeeò, The Nonproliferation Review, 7(2000): 138; Daniel Joyner, International Law and the Proliferation of Weapons of Mass Destruction,(Oxford University Press, 2009); Tariq Rauf, ñExport Controls and Multilateral Nuclear Arrangementsò, in Nuclear Proliferation and International Security, Morton Bremer Mærli and Sverre Lodgaard (ed.) (Routledge Global Security Studies, 2007), 296.

5 - United States, United Kingdom, Soviet Union, Canada, Germany, and Japan.

${ }^{6}$ - Text of the NFCIRC/254 available at http://www.iaea.org/Publications/Documents/Infcircs/Others/infcirc254.shtml

7 - Newsbrief, Program for Promoting Nuclear Non-Proliferation, (Great Britain: Third Quarter 1997), 2.

8 - INFCIRC/539/Rev.4 available at http://www.nuclearsuppliersgroup.org/Leng/05-pubblic.htm

9 - ñThe NSG Guidelinesò, The Nuclear Suppliers Group.

Available at

http://www.nuclearsuppliersgroup.org/Leng/05-pubblic.htm

10 - "1995 NPT Review Conference Package of Decisions" available at http://www.reachingcriticalwill.org/legal/npt/1995dec.html\#2

11 - "2000 NPT Review Conference Final Document" available at http://www.armscontrol.org/act/2000_06/docjun

ñ2010 NPT Review Conference Final Documentò available at http://www.un.org/ga/search/view_doc.asp?symbol=NPT/CONF.2010/50\%20(VOL.I)

12 - The Consultative Group is the NSGô ñstanding intersessional working body.ò Available at http://www.nuclearsuppliersgroup.org/activities.htm.

13 - Daryl Kimbal, "U.S. Proposal for Changes to Nuclear Suppliers Group Guidelines Circulated March 2006", Arms Control Association, March 27, 2006.

14 - Copy of the draft is available at http://www.armscontrol.org/projects/india/20060327_DraftNSGProposal

15 - Siddharth Varadarajan, ñIndia Bracing itself for American Draftò, The Hindu, July 26, 2008.

16 - The copy of the draft is available at http://www.armscontrol.org/node/3274

17 - Boris Groendahl, ñU.S. Proposes India Nuclear Waiver approval in Doubtò, Reuters, August 14, 2008.

18 - Siddharth Varadarajan, ñNSG critics focus on non-proliferation benchmarksò, The Hindu, August 22, 2008.

19 - Siddharth Varadarajan, ñFinding a Fix to the NSGố Code of Omertaò, The Hindu, August 23, 2008.

20 - John Morris, ñAustria to keep quite over Indian nuclear ambitionsò, austriantimes, August 11, 2008.

21 - Siddharth Varadarajan, ñTighten Draft Waiver for Indiaò, The Hindu, August 16, 2008.

22 - Mary Fitzgerald, ñreland Cautious on Nuclear Trdae Deal for Indiaò, The Irish Times, August 22, 2008.

23 - Mark Heinrich, ñNuclear Suppliers meet on U.S.-India Trade Dealò, Reuters, August 21, 2008.

24 - Siddharth Varadarajan, ñIndia says NSG clearance is U.S. responsibilityò, The Hindu, August 23, 2008.

25 - Siddharth Varadarajan, "India says NSG clearance is U.S. responsibility", The Hindu, August 23, 2008.

26 - Siddhart Varadarajan, "Conditions mooted for Indian Nuclear Waiver", The Hindu, August 23, 2008.

27 - Praful Bidwai, ñNuclear Deal headed for fiascoò, Inter Press Services (IPS), August 28, 2008.

28 - Ibid.

29 - Ibid.

${ }^{30}$ - ñThe NSG in a time of change: An interview with NSG Chairman Piet de Klerkò, Arms Control Today, October 2011.

31 - Siddharth Varadarajan, ñNSG Statement by the óGang of Sixô, The Hindu, August 26, 2008.

32 - UN Security Council Resolution 1172, India/Pakistan, June 6, 1998. Available at http://www.un.org/Docs/scres/1998/scres98.htm

33 - Copy of the draft is available at http://www.armscontrol.org/node/3331

34 - ñNuclear Suppliers Group mulls India waiver amid continuing skepticismò, BBC Monitoring South Asia, September 04, 2008.

35 - Mark Heinrich, ñNuclear Nations approve disputed India trade waiverò, Reuters, September 06, 2008.

36 - Siddharth Varadarajan, ñLast-ditch talks on to avert NSG dead-endò, The Hindu, September 05, 2008.

37 - Mark Heinrich, ñNuclear Nations approve disputed India trade waiverò, Reuters, September 06, 2008. 


\section{Sario Bano}

38 - Siddharth Varadarajan, ñNSG meets again amidst rumblings of uncertaintyò, The Hindu, September 04, 2008.

39 - Siddharth Varadarajan, ñNSG hopeful of Consensus Soonò, The Hindu, September 05, 2008.

40 - Ibid

41 - Ibid

$72 \quad 42$ - Ibid

43 - Siddharth Varadarajan, ñLast-ditch talks on to avert NSG dead-endò, The Hindu, September 05, 2008.

44 - Statement by External Affairs Minister of India Shri Pranab Mukherjee on the Civil Nuclear Initiative. Available at http://www.mea.gov.in/mystart.php?id=290014162

45 - Statement by External Affairs Minister of India Shri Pranab Mukherjee on the Civil Nuclear Initiative.

Available at http://www.mea.gov.in/mystart.php?id=290014162

46 - Siddharth Varadarajan, ñThirty words that saved the dayò, The Hindu, September 09, 2008.

47 - Siddharth Varadarajan, ñLast-ditch talks on to avert NSG dead-endò, The Hindu, September 05, 2008.

48 - Siddharth Varadarajan, ñThirty words that saved the dayò, The Hindu, September 09, 2008.

49 - Copy of the draft is available at http://www.armscontrol.org/node/3345

50 - Daryl Kimball, ñText, Analysis, and Response to NSG ñStatement on Civil Nuclear Cooperation with Indiaò, Arms Control Association, September 06, 2008. Available at http://www.armscontrol.org/node/3345

51 - J. Sri Raman, ñHow Indiaôs Nuclear ớWaiverôwas Wonò, Truthout, September 09, 2008.

52 - Mark Heinrich, ñNuclear Nations approve disputed India trade waiverò, Reuters, September 06, 2008.

53 - Mark Heinrich, ñNuclear Nations approve disputed India trade waiverò, Reuters, September 06, 2008.

54 - Siddharth Varadarajan, ñNSG Waiver Enables Member States to Provide India Full Civil Nuclear Cooperationò, The Hindu, September 07, 2008.

55 - Mark Mitchell, ñNZ Backs Nuclear Exemption for India after Pressureò, New Zealand Herald, September 08, 2008.

56 - Glenn Kessler, ñWorld Nuclear Trade Group Agrees to Restrict ñ, The Washington Post, September 12, 2008.

57 - Siddharth Varadarajan, ñNSG Waiver Enables Member States to Provide India Full Civil Nuclear Cooperationò, The Hindu, September 07, 2008.

58 - Daryl Kimball, ñText, Analysis, and Response to NSG ñStatement on Civil Nuclear Cooperation with Indiaò, Arms Control Association, September 06, 2008.

59 - Mark Hibbs, ñUS pressing for NSG exemption for India by end of this weekò, Nucleonics Week, 49(2008).

${ }^{60}$ - Mark Heinrich, ñNuclear Nations approve disputed India trade waiverò, Reuters, September 06, 2008.

${ }^{61}$ - Somini Sengupta and Mark Mazzetti, ñNuclear Suppliers Group ends ban on tradeò The New York Time, September 07, 2008.

62 - Statement by S. Banerji at the $54^{\text {th }}$ General Conference, Vienna, September 22, 2010. Available at www.dae.gov.in/

63 - "US to support India's full membership in NSG", The Times of India, November 06, 2010.

64 - India-US Joint Statement on November 8, 2010 available at http://www.whitehouse.gov/the-press-office/2010/11/08/joint-statement-president-obama-and-prime-ministersingh-india

65 - ñIndia Tightens Atomic Transfer Controlsò, Global Security Newswire, March 14, 2013.

66 - Nirupama Rao, Indian Ambassador to the United States, comments at 2013 Carnegie International Nuclear Policy Conference. April 8-9 2013 available at http://carnegieendowment.org/2013/04/09/is-there-emergingpower-agenda/fx28

67 - "Sarkozy backs India for UNSC, NSG", The Economic Times, December 4, 2010

68 - "Germany backs India for NSG membership", The Economic Times, December 7, 2010

69 - "Russia backs India for NSG", Hindustan Times, December 21, 2010.

70 - ñAustralia Commits NSG Supportò, Indo-Asian News Service, May 3, 2012.

71 - Fredrik Dahl, ñBritain Lobbies for Nuclear Export Group to Admit Indiaò, Reuters, June 14, 2013.

72 - Nuclear Suppliers Group Point of Contact Note, United States Communicationð ñFood for ThoughtòPaper on Indian NSG Membership, May 23, 2011, www.armscontrol.org/system/ files/nsg1130.pdf.

73 - Daniel Hornes, ñNSG Revises Rules on Sensitive ExportsòArms Control Today, July/August 2011.

74 - ñOn what basis are participation decision are taken?ò available at http://www.nuclearsuppliersgroup.org/A_test/01-eng/06-parti.php?\%20button=6

75 - Fredrik Dahl, ñBritain Lobbies for Nuclear Export to Admit Indiaò, Reuters, June 14, 2013. 


\footnotetext{
76 - ñDebate persists over Indian entry to nuclear export groupò, Nuclear Threat Initiative, March 21, 2013.

77 - Fredrik Dahl, ñNuclear States Divided on India Joining Export Control Groupò, Reuters, March 20, 2013.

78 - Daniel Hornes, ñNSG Revises List, Continues India Debateò, Arms Control Today, July/August 2013.

79 - Fredrik Dahl, ñNuclear States Divided on Indiaôs Joining Export Control Groupò Reuters, March 21, 2013.

80 - Pierre Goldschmidt and Toby Dalton, ñConditions on Indian NSG membershipò, Proliferation Analysis, June 14, 2011.

81 - Daryl Kimball, ñNew Nuclear Suppliers Rules a Net Plusò Arms Control Today, July/August 2011.

82 - ñIndiaố Nuclear Amateurismò, Daily the Post, July 1, 2013.

83 - G. Balachandran, ñIndia and the NSG: Approaches to Indian MembershipòInstitute for Defence Studies and Analysis (IDSA), May 23, 2013.

84 - India to Lobby for Joining Nuclear Suppliers Group", Global Security Newswire, January 31,2011.

85 - ñIndia to Argue for Entry into Atomic Export Groupò, Nuclear Threat Initiative. February 29, 2012.

86 - ñIndiaQ̂s NSG Entry Unlikely SoonòThe Financial Express, June 21, 2013.

87 - Fred McGoldrick, ñA Road Ahead for Export Controls: Challenges for the Nuclear Suppliers Groupò, Arms Control Today, January/February 2011.

88 - Daniel Painter, ñThe Nuclear Suppliers Group at the Crossroadsò, The Diplomat, June 10, 2013.
} 